\title{
Are the RNA:DNA ratio and dry-weight-at-length suitable growth proxies for brown shrimps (Crangon crangon)?
}

\author{
Marc Hufnagl, Axel Temming \\ Institute for Hydrobiology and Fishery Science, Olbersweg 24, 22767 Hamburg, Germany. \\ (MH) (Corresponding author) E-mail: marc.hufnagl@ uni-hamburg.de. ORCID iD: https://orcid.org/0000-0003-1873-3715 \\ (AT) E-mail: atemming@uni-hamburg.de. ORCID iD: https://orcid.org/0000-0002-0653-0614
}

\begin{abstract}
Summary: Growth rates are of fundamental interest for studying population dynamics of species when no age information is available. In these cases in situ growth proxies must be identified and validated, and here we tested whether RNA-DNA ratio (RD) and dry weight condition (DWC) can act as such proxies for the shrimp Crangon crangon. Growth rates (mm $\mathrm{d}^{-1}$ ) were determined for male and female shrimps $(20$ to $67 \mathrm{~mm})$ reared at five different temperatures $\left(5^{\circ} \mathrm{C}\right.$ to $\left.25^{\circ} \mathrm{C}\right)$ and caught in two different months (May, July). Due to the potential interactive effects of the factors sex, size, temperature and time, different statistical analysis were applied to test for linear interactions (factorial analysis of mixed data, FAMDs), nonlinear additive effects (generalized additive models, GAMs) and nonlinear interactions (nonlinear regression combined with GAMs). The FAMD indicated positive correlations between length, month and growth rate. A positive correlation between DWC and sex and between RD and temperature was also indicated. RD was not significant in the GAM but a nonlinear link between length, temperature and growth was found. Finally, an extended Bertalanffy growth model was fitted to sex-specific growth rates and in a second step a GAM was fitted to the differences (residuals) between observed and predicted growth. RD again had no significant explanatory power for growth and, although it is a commonly used growth proxy, we concluded that it is not a suitable index for evaluating length growth of C. crangon.
\end{abstract}

Keywords: Crangon crangon; growth; dry weight; RNA: DNA; GAM; FAMD.

¿La relación ARN:ADN y el peso en seco a la longitud son indicadores adecuados para determinar el crecimiento de la quisquilla gris (Crangon crangon)?

Resumen: En el estudio de las dinámicas poblacionales de las especies, y en particular en las que no se dispone de información sobre la edad de los individuos, es fundamental conocer las tasas de crecimiento. Por lo tanto, es necesario identificar y validar las aproximaciones sobre estimación de crecimiento in situ adecuados. En este estudio se ha analizado si la relación ARN-ADN (RD) y la condición de peso seco (DWC) pueden actuar como indicador para la estimación de crecimiento en el camarón Crangon crangon. Se determinaron las tasas de crecimiento $\left(\mathrm{mm} \mathrm{d}^{-1}\right)$ para los camarones macho y hembra capturados $\left(20\right.$ a $67 \mathrm{~mm}$ ) en dos meses diferentes (mayo, julio) y cultivados a cinco temperaturas diferentes $\left(5\right.$ a $25^{\circ} \mathrm{C}$ ). Debido a los posibles efectos interactivos de los factores como sexo, tamaño, temperatura y tiempo, se aplicaron diferentes análisis estadísticos para probar las interacciones lineales (FAMD: análisis factorial de datos mixtos), efectos aditivos no lineales (modelos aditivos generalizados, GAMs) y interacciones no lineales (regresión no lineal combinada con GAMs). La FAMD indicó correlaciones positivas entre la duración, el mes y la tasa de crecimiento. También se observó una correlación positiva entre DWC y sexo, y entre RD y temperatura. La RD no fue significativa en el GAM, pero se encontró un vínculo no lineal entre la longitud, la temperatura y el crecimiento. Finalmente, se adaptó un modelo de crecimiento ampliado de Bertalanffy a las tasas de crecimiento específicas por sexo y, en un segundo paso, se adaptó un GAM a las diferencias (residuales) entre el crecimiento observado y el previsto. De nuevo RD no tenía un poder explicativo significativo para el crecimiento y aunque es un indicador de crecimiento utilizado comúnmente, concluimos que no es un índice adecuado para evaluar el crecimiento de longitud de $C$. crangon.

Palabras clave: Crangon crangon; crecimiento; peso seco; ARN:ADN; GAM; FAMD.

Citation/Como citar este artículo: Hufnagl M., Temming A. 2018. Are the RNA:DNA ratio and dry-weight-at-length suitable growth proxies for brown shrimps (Crangon crangon)? Sci. Mar. 82(1): 43-54. https://doi.org/10.3989/scimar.04530.05A

Editor: J. Viñas.

Received: August 5, 2016. Accepted: February 5, 2018. Published: February 19, 2018.

Copyright: () 2018 CSIC. This is an open-access article distributed under the terms of the Creative Commons Attribution 4.0 International (CC BY 4.0) License. 


\section{INTRODUCTION}

One of the fundamental variables in population analysis and ecology is age, as only with age factors such as maximum lifespan, productivity, sensitivity to the environment, reproduction rates and general life cycle can a population be described precisely. If no age information is available, age can be estimated from length and growth, but growth is influenced by factors such as energy availability, experienced temperatures, behaviour and physiological condition, and thus undergoes high variations. The aim of this study was to identify factors that explain this variability and that help us to determine growth rates accurately from field samples.

Crustaceans moult regularly, which leads to a loss of hard parts and all easily accessible age information (Hartnoll 2001), so ageing of crustaceans remains a challenging task. Although new methods for ageing shrimps have been developed recently (Kilada et al. 2012), these methods might, like the age pigment lipofuscin (Sheehy et al. 1999), not be suitable for all crustaceans and especially not the short-lived species. A solid management or a sound understanding of the population biology of these species is therefore only possible if good growth information is available to allow for a conversion of observed length to age. Here, the uncertainty in the age information gained from length increases significantly if individual growth is variable or not determinable in situ, e.g. due to common restrictions of cohort analysis (following the progression of length modes). Cross validations between field and laboratory studies are either few in number or not straightforward due to rearing biases and variable field conditions. A better length-age conversion could be obtained if robust proxies were available. Even a separation from slow and fast growing individuals would be of use.

For brown shrimp (Crangon crangon) such a proxy would be of interest because it is heavily exploited in the southern North Sea, it is not managed so far, partly due to missing age information, and, with a total exponential mortality of $\mathrm{Z}>5 \mathrm{a}^{-1}$ (Hufnagl et al. 2010), the vast majority of the shrimps grow no older than two years, so age proxies such a lipofuscin are not applicable. More specifics on the general life cycle of the shrimp can be found elsewhere (Tiews 1970, Campos and van der Veer 2008, Siegel et al. 2008).

Reviewing the literature on $C$. crangon growth, we found a high growth variability within and between single studies (Hufnagl and Temming 2011b). Weight growth is seldom measured as it is unreliable, so we focused on total length growth. Growth rates for 20- to 30 -mm-sized shrimps (total length, TL) at $20^{\circ} \mathrm{C}$ has been reported to be $0 \mathrm{~mm} \mathrm{~d}^{-1}$ (Edwards 1978), about 0.2 $\mathrm{mm} \mathrm{d}^{-1}$ (van Lissa 1977) and $0.5 \mathrm{~mm} \mathrm{~d}^{-1}$ (Dalley 1980). Even under ad libitum feeding conditions, growth variability has remained high for reasons that are so far unknown (Hufnagl and Temming 2011a, b). Individual differences in the genome, feeding behaviour or adaptation to winter conditions might be possible reasons but have not been tested systematically so far.
If we assume that the growth variability, observed between and within different studies, is related to different feeding behaviour (e.g. individual intake rates), preferences, activity, or different life histories (e.g. metabolic adaptation leading to lower activity and/or lower consumption and respiration rates), then this should be measurable. Protein synthesis or cell activity can, for example, be determined by the RNA content in a cell or by deriving other condition proxies such as dry weight in relation to length. Analysing and understanding the relation between growth and these proxies could help to better understand and describe the population structure, the seasonal cycle and the maximum age.

RNA.DNA ${ }^{-1}$ (RD) is a commonly used proxy for individual growth (see references below). The amount of RNA in a cell is assumed to correlate with protein synthesis, and thus with nutrition and growth, whereas the amount of DNA, the carrier of genetic information, is assumed to be constant in the majority of cell types. Among a variety of species, significant correlations of $\mathrm{RD}$ and growth have been reported, for example, in larval fish (Hovenkamp and Witte 1991, Buckley et al. 1999, Peck et al. 2003), corals (Buckley and Szmant 2004), scallops (Lodeiros et al. 1996) and crustaceans such as Artemia (Dagg and Littlepage 1972), Homarus (Juinio and Cobb 1994), Penaeus (Moss 1994a, 1994b) and Calanus (Wagner et al. 1998). However, in a number of studies no correlations were determined (Mathers et al. 1994, Lee et al. 2006, Norkko et al. 2006), indicating that a priori testing and calibration of this proxy is required

Hufnagl et al. (2010) found that, in starvation experiments and in field-caught animals, RD and DWC were meaningful proxies describing short-term starvation processes. Thus, RD and DWC have the potential to indicate nutrition history, leading to the question whether both measures can also be applied as growth proxies.

The aim of this study was therefore to determine whether RD and DWC are suitable in situ growth proxies for the brown shrimp Crangon crangon and whether or how temperature, shrimp size, sex and time of the year will influence these proxies.

\section{MATERIALS AND METHODS}

\section{Growth experiments}

Growth experiments were performed at the "AWIBiological Institute Helgoland" between 15 May and 11 August 2006. Temperatures (T) of $5^{\circ} \mathrm{C}, 10^{\circ} \mathrm{C}, 15^{\circ} \mathrm{C}$, $20^{\circ} \mathrm{C}$ and $25^{\circ} \mathrm{C}$ and shrimps of 20 to $67 \mathrm{~mm}$ TL were used. Conditions, preliminary handling, catch area, feeding and a detailed analysis of the observed growth, mortality and moult rates are described in detail in Hufnagl and Temming (2011a). A combined analysis of the data in relation to growth rates (GRs) obtained by other authors was given in Hufnagl and Temming (2011b). Only a short description of the experimental design will thus be given here.

Shrimps were reared in groups distributed over 73 aquaria. In 50 aquaria all individuals were marked with coloured plastic marks to track individual growth and 
moult rates. No negative effects on growth or mortality were observed using this treatment. In the remaining 24 aquaria, the animals were sorted to one initial length, and growth was determined from the difference between start and end length divided by rearing time.

Shrimps were caught on 8 and 9 May on a cruise with the research vessel Uthörn in the Weser $\left(58^{\circ} 49^{\prime} \mathrm{N}\right.$, $\left.8^{\circ} 10^{\prime} \mathrm{E}\right)$, Elbe $\left(54^{\circ} 02^{\prime} \mathrm{N}, 8^{\circ} 20^{\prime} \mathrm{E}\right)$ and Eider (54 ${ }^{\circ} 17^{\prime} \mathrm{N}$, $8^{\circ} 27^{\prime} \mathrm{E}$ ) estuaries between 4 and $8 \mathrm{~m}$ water depth. Due to the large mesh sizes used on board, no small shrimps were collected during the first sampling. Furthermore, small shrimps prefer shallow water and were therefore obtained "on foot" using a push net (1.8 $\mathrm{mm}$ mesh size) off the coast of Büsum, Germany $\left(54^{\circ} 07^{\prime} \mathrm{N}, 8^{\circ} 51^{\prime} \mathrm{E}\right)$ in about $1 \mathrm{~m}$ water depth on 12 May and 10 July.

All shrimps were fed daily with live polychaetes (Nereis spec., Lanice conchilega), green algae (Ulva lactuca) and live plankton. The plankton was obtained from regular samplings performed off the island of Helgoland every workday using a $280-$ and $500-\mu \mathrm{m}$ mesh (Greve et al. 2004). Shrimps were reared at $5^{\circ} \mathrm{C}$, $10^{\circ} \mathrm{C}, 15^{\circ} \mathrm{C}, 20^{\circ} \mathrm{C}$ and $25^{\circ} \mathrm{C}$ and $31.7 \pm 0.6$ psu in closed recirculation systems with $50 \%$ daily water exchange. Only shrimps that spent at least one complete moult cycle plus ten days in the experiment tank at the rearing temperature were used for later analysis. This was done to make sure that no external uncontrolled factors from the time the animal had spent outside the laboratory would influence the results.

For marked animals, GR was obtained from the last observed moult increment (difference between pre- and post-moult length) divided by the inter-moult period. For all pre-sorted unmarked shrimps, the length was determined at the beginning and at the end of each experiment. Wet weight was not tracked during the experiment due to high measurement uncertainties and to avoid handling stress. Dry weight was determined at the end of the experiment. By dividing individual dry weight by the general length-dry weight relation of $1.30110^{-6} \cdot \mathrm{L}^{3.06}\left(\mathrm{r}^{2}=0.977, \mathrm{n}=8305\right.$, Hufnagl et al. 2010), dry weight condition (DWC) was obtained for each shrimp. Values larger (smaller) than one indicated a higher (lower) dry weight than the average shrimp.

\section{Determination of the RNA:DNA ratio}

RD was based on fluorescence measurements following largely the procedure described by Caldarone et al. (2001). Deviations from their method, accuracy of the analysis and application of the method to $C$. crangon collected in the field and reared in the laboratory were described in Hufnagl et al. (2010). RD was determined from freeze-dried muscle samples $\left(3^{\text {rd }}\right.$ segment). Samples were homogenized and dissolved. After adding of the fluorescence marker ethidium bromide, a first baseline fluorescence measurement was taken. After digestion of the RNA in the sample using RNAse, the second fluorescence measurement was taken. After digestion of the DNA by DNAse, the third measurement was taken. From the differences between the fluorescence values and by internal calibration (on the same 96-well plate) with a DNA and RNA standard, the amount of RNA and DNA and the RNA-DNA ratio were determined. Each sample was measured twice.

\section{Statistical analysis}

For each shrimp the following factors were available: RD, TL (mm), DWC, rearing temperature $\left(\mathrm{T},{ }^{\circ} \mathrm{C}\right)$, sex (juvenile, male, female) and catch month (May, July). In total 666 shrimps were analysed, 36 juveniles (sex could not be defined), 175 males, 389 females and 66 females with eggs (female+). Numbers per length class (ranges from 20 to $29 \mathrm{~mm}, 30$ to $39 \mathrm{~mm}$, etc.) were $12(20 \mathrm{~mm}), 107(30 \mathrm{~mm}), 261(40 \mathrm{~mm}), 175(50$ $\mathrm{mm}), 111(60 \mathrm{~mm})$, respectively. At $5^{\circ} \mathrm{C}, 10^{\circ} \mathrm{C}, 15^{\circ} \mathrm{C}$, $20^{\circ} \mathrm{C}$ and $25^{\circ} \mathrm{C}, 123,189,155,137$ and 62 animals were reared, respectively.

Due to the number of interacting factors and the complexity of the data set, we chose different approaches to identify whether RD and DWC are suitable growth proxies:

1) Data were split by sex and the level of RD or DWC and the observed GRs were compared. In this analysis temperature and shrimp length were not included. 2) A factorial analysis of mixed data (FAMD) was used to identify the importance of all available variables and to identify whether and which variables were linearly related. The FAMD is comparable to a principle component analysis but accounts for qualitative and quantitative variables at the same time. The FAMD will not account for direct nonlinear effects. 3) A generalized additive model (GAM) was used to identify nonlinear additive effects including all factors (T, TL, sex, month, RD, DWC). As GAMs account for additive but not for nonlinear interactive effects, 4) the first derivative of the von Bertalanffy growth function, expanded with a temperature term, was fit to the sex specific growth observations to allow for a description of growth by sex, length and temperature. We tried to explain the remaining variability by accounting for RD and DWC. Again, a GAM was used to identify whether the variability of the residuals (observed growth - predicted growth) can be explained by RD or DWC.

\section{Analysis 1. Direct effect of RD and DWC}

RD and DWC were rounded to the nearest 0.1 values and all female and male GRs were pooled by their corresponding RD and DWC values. All GRs in each bin were tested for normal distribution and variance homogeneity using Kolmogorov-Smirnov and Leven tests, respectively. If no normal distribution or variance homogeneity was determined, Mann-Whitney-U tests were applied to test for significant differences between groups.

\section{Analysis 2. Linear interaction of variables: FAMD}

The FAMD included all quantitative (RD, DWC, GR, TL) and qualitative ( $\mathrm{T}$, sex, month) variables. Temperature included five classes, $5^{\circ} \mathrm{C}, 10^{\circ} \mathrm{C}, 15^{\circ} \mathrm{C}$, $20^{\circ} \mathrm{C}$ and $25^{\circ} \mathrm{C}$; sex included female, male, female+ 
(egg carrying) and juvenile; and month included May and July. FAMD was calculated using R 3.2.2 and the package FactoMineR (Lê et al. 2008).

\section{Analysis 3. Nonlinear additive effects of variables: GAMs}

GAMs were calculated using the $\mathrm{R}$ package "mgcv". No interactive effects were taken into account and qualitative and quantitative variables were used as described under Analysis 2, with one difference: here temperature was applied as quantitative variable.

The analysis was started using a full model including all variables:

$\mathrm{GR}=\mathrm{s}(\mathrm{RD})+\mathrm{s}(\mathrm{L})+\mathrm{s}(\mathrm{DWC})+\mathrm{s}(\mathrm{T})+$ gender + month

Starting from this full model, all significant parameters $(p<0.05)$ were kept while all non-significant parameters and interactions were rejected and the model was refitted without them. Several error distributions ("Gaussian", "Poisson", "Negative binomial" and "Gamma") were tested and the model with the lowest Akaike information criterion (AIC) was finally used. The number of dimensions of all smooth terms was set to $k=5$.

\section{Analysis 4. Analysing residuals of observed and} predicted $G R$

Von Bertalanffy (1934) explained growth as the difference between anabolism and catabolism:

$$
\frac{d W}{d t}=H \cdot W^{\frac{2}{3}}-k \cdot W
$$

where $W$ is the weight, $k$ the catabolic constant, equivalent to \% weight loss per time in starving individuals, and $H$ the anabolic constant, related to food intake and synthesis of body mass. In Hufnagl and Temming (2011b) we expanded this growth model, after transformation, so length growth is represented with a temperature term:

$$
\frac{d L}{d t}=a+b \cdot T-c \cdot e^{d \cdot T} \cdot L
$$

The term $c \cdot e^{d \cdot T}$ with constants $c$ and $d$ represents the von Bertalanffy length growth factor $K$ (upper case as this is the length-based growth factor in relation to the $k$ before, which is the weight-based factor), where $a$ and $b$ are constants. In Hufnagl and Temming (2011b) this model was fitted to growth data obtained from 25 different studies yielding an $\mathrm{r}^{2}$ of 0.87 and a parameter " $a$ " not significantly different from zero, which was therefore omitted. Owing to the good representation of the data, the same growth model was applied in this study, fitting $b, c$ and $d$ to observed sex specific GRs and to all GRs, including also juveniles. Residuals were determined as Res = observed growth - predicted growth. For juvenile shrimps the general model was applied to predict growth.

Variability in growth residuals was analysed using GAMs as described above.
$\operatorname{res}_{\mathrm{GR}}=\mathrm{s}(\mathrm{RD})+\mathrm{s}(\mathrm{L})+\mathrm{s}(\mathrm{DWC})+\mathrm{s}(\mathrm{T})+$ gender + month

Although the growth model already accounted for T and L effects, these parameters were included to identify potential biases in the model and its goodness of fit.

\section{RESULTS}

\section{Growth rates}

Mean GRs were lowest at $5^{\circ} \mathrm{C}$ and $10^{\circ} \mathrm{C}$, with values $<0.1 \mathrm{~mm} \mathrm{~d}^{-1}$ for all size classes. In general, growth decreased with increasing body length and increased with increasing temperatures. Highest mean GRs $\left(0.56 \mathrm{~mm} \mathrm{~d}^{-1}\right)$ were observed for animals that did not overwinter (those caught in July), which had a start length of $20 \mathrm{~mm}$ and were reared at $25^{\circ} \mathrm{C}$. Lowest GRs $\left(0.02 \mathrm{~mm} \mathrm{~d}^{-1}\right)$ were observed for overwintered adult shrimps $(60 \mathrm{~mm})$ reared at $10^{\circ} \mathrm{C}$. Females grew on average $0.1 \mathrm{~mm} \cdot \mathrm{d}^{-1}$ faster than males at comparable TL and T.

\section{Analysis 1. Direct effect of RD and DWC}

Higher median GRs were related to higher RD, but variability was generally high for male as well as for female shrimps (Fig. 1). Data were not normal distributed (KS, $\mathrm{p}>0.05)$, so Mann-Whitney-U tests were used to compare classes. Male shrimps with $\mathrm{RD}<0.5$ displayed significantly lower GRs than those with $\mathrm{RD}>1$. Female shrimps with $\mathrm{RD}<0.4$ displayed significantly lower GRs than those with RD between 0.8 and 1.1. Variability was higher for female than for male shrimps. Shrimps with higher DWC also showed significantly higher GRs (Fig. 1).

\section{Analysis 2. Linear interaction of variables: FAMD}

Variables GR, month and TL were closely linked to axis 1 , which explained $25 \%$ of the variance (Fig. 2). Variables DWC and sex were linked to axis 2, which explained $13 \%$ of the variance. Axes 3 to 5 (not shown) explained $11 \%, 10 \%$ and $9 \%$ of the variance. Variables $\mathrm{RD}$ and $\mathrm{T}$ were linked to both the first and the second axis. A high positive correlation was indicated for GR, TL, RD and month, while the variables representation indicated only a weak relation between month and DWC or month and sex.

In the individual factor map the variable temperature was represented by the first and second axis, while month was fully described by the first axis. Distributions of individuals, when described by axis 1 and axis 2 , were also significantly different from zero on axis 1 for $25^{\circ} \mathrm{C}$ and on axis 2 for May and July as here $-2<$ v.test $<2$ (Table 1). The v.test further indicated that shrimps from the $5^{\circ} \mathrm{C}$ experiment were significantly located on the negative parts of both axes (v.test for $\operatorname{dim} 1$ and $\operatorname{dim} 2<-2$ ), while those of the $15^{\circ} \mathrm{C}$ experiment were located on the positive sides (positively associated with axes 1 and 2), which can also be seen in Figure 2. 

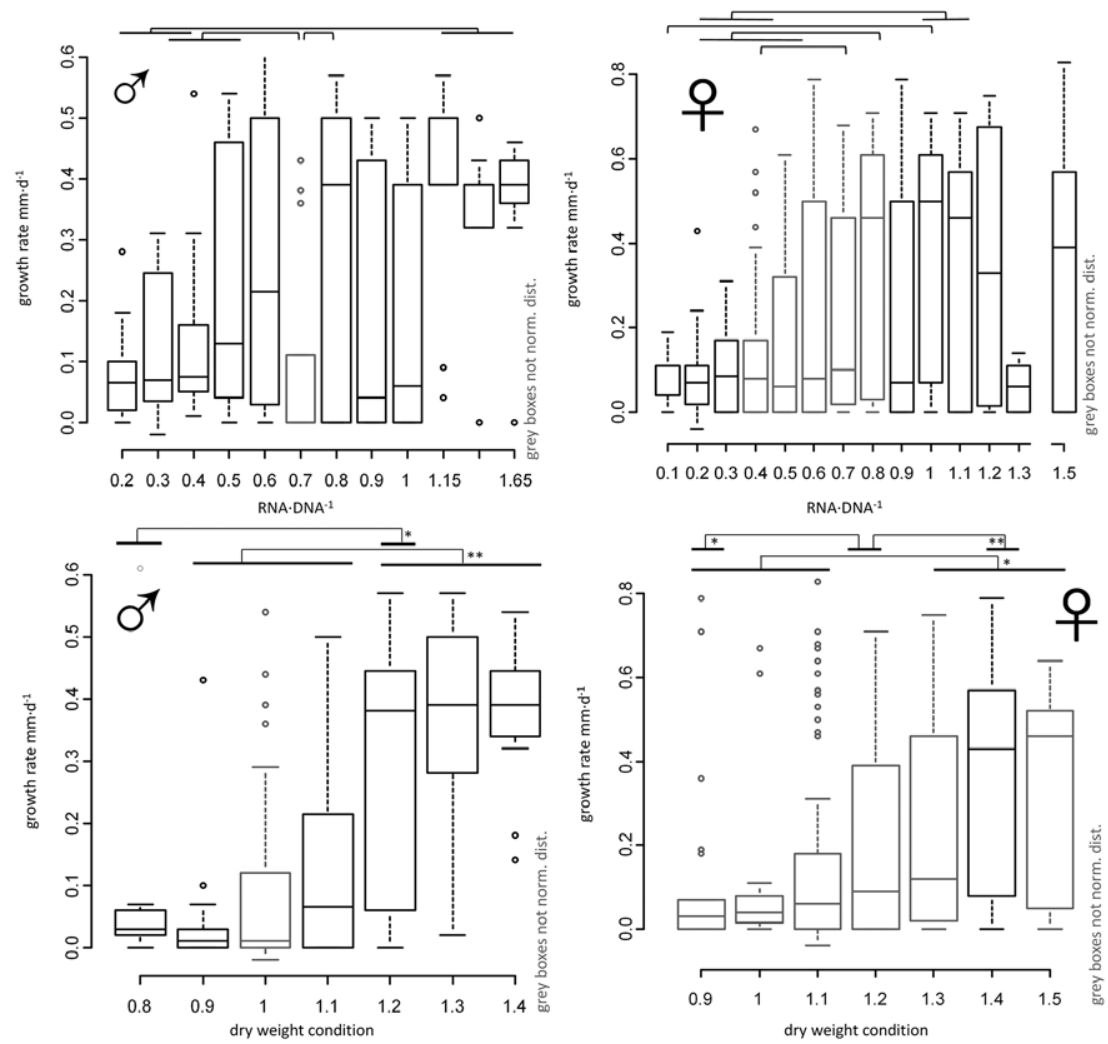

Fig. 1. - Boxplots of growth vs. RNA.DNA ${ }^{-1}$ (top panels) and dry weight condition (lower panels) for male (left) and female (right) shrimps. Lines above the boxes indicate groups which were not significantly different. Light grey boxes indicate groups which were not normally distributed.
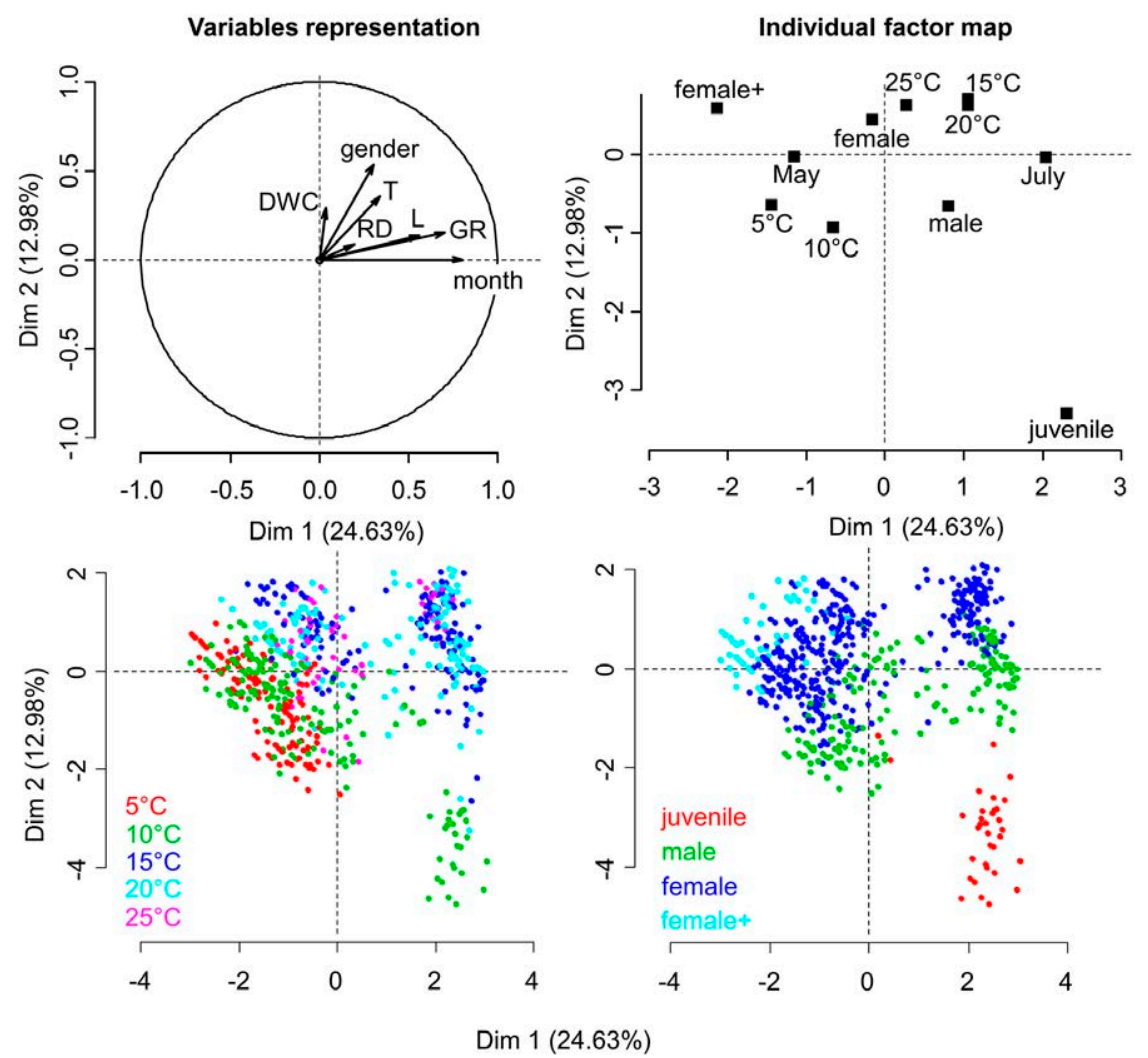

Fig. 2. - Result of the factorial analysis of mixed data. Top left, variables representation; top right, factor map; lower panels, observations by first and second dimension coloured either by the temperatures the shrimps experienced (lower left) or the sex of the shrimp (lower right), where female+ are egg-carrying shrimps. 
Table 1. - Results of the factorial analysis of mixed data. Upper parts shows the results for qualitative variables, the lower part for the quantitative variables. For both sets of variables their contribution to dimension 1 and 2 , and for the qualitative variables also the results of the v.test.

\begin{tabular}{lccccc}
\hline & Variable & ctr to Dim 1 & v.test & ctr to Dim 2 & v.test \\
\hline qualitative & juvenile & 3.2 & 7.9 & 23.4 & -15.6 \\
variables & male & 1.8 & 6.7 & 4.2 & -7.5 \\
& female & 0.3 & -3.4 & 5.4 & 11.4 \\
& female+ & 5.2 & -10.4 & 1.5 & 4.1 \\
& $5^{\circ} \mathrm{C}$ & 4.8 & -10.5 & 2.9 & -6.0 \\
& $10^{\circ} \mathrm{C}$ & 1.5 & -6.2 & 9.4 & -11.4 \\
& $15^{\circ} \mathrm{C}$ & 2.7 & 8.1 & 5.1 & 8.1 \\
& $20^{\circ} \mathrm{C}$ & 2.6 & 7.8 & 3.8 & 6.9 \\
& $25^{\circ} \mathrm{C}$ & 0.1 & 1.1 & 1.7 & 4.3 \\
& $\mathrm{May}$ & 10.1 & -22.7 & 0.0 & 0.1 \\
quantitative & $\mathrm{July}$ & 17.2 & 22.7 & 0.0 & -0.1 \\
variables & $\mathrm{RD}$ & 0.442 & & -0.293 & \\
& $\mathrm{~L}$ & -0.751 & & 0.37 & \\
& $\mathrm{GR}$ & 0.84 & & 0.389 & \\
\hline & $\mathrm{DWC}$ & 0.187 & & 0.539 & \\
\hline \multirow{5}{*}{} & & & & &
\end{tabular}

\section{Analysis 3. Nonlinear additive effects of variables:} GAMs

RD was not but all other variables were significant $(\mathrm{p}<0.05$, Table 2$)$, so the final GAM was
Table 2. - Values obtained from the generalized additive model used in Analysis 2: Nonlinear additive effects of variables. Table includes the number of knots k', estimated degree of freedom (edf), $\mathrm{k}$-index and the significance value $\mathrm{p}$.

\begin{tabular}{lcccc}
\hline & $\mathrm{k}^{\prime}$ & edf & k-index & p-value \\
\hline s(L) & 4 & 3.33 & 0.68 & 0 \\
s(DWC) & 4 & 3.197 & 0.91 & 0.02 \\
s(T) & 4 & 3.935 & 0.53 & 0 \\
\hline
\end{tabular}

$\mathrm{GR}=\mathrm{s}(\mathrm{L})+\mathrm{s}(\mathrm{DWC})+\mathrm{S}(\mathrm{T})+$ gender + month $\left(r^{2}=0.773\right.$, deviance expl. $\left.77.8 \%\right)$.

Excluding the factors sex or month neither decreased the AIC nor increased the explained deviance, so both factors were kept. Estimated degrees of freedom ranged between 3 and 4 and the k-index was 0.91 , 0.69 and 0.53 for DWC, L and T, respectively.

Between 20 and $40 \mathrm{~mm}$ TL, the regression spline increased with size and decreased again, but with a shallower slope, for larger sizes (Fig. 3). The DWC regression spline increased with increasing values. The temperature smoother was on a comparable level for $5^{\circ} \mathrm{C}$ and $10^{\circ} \mathrm{C}$ and on a higher level for $15^{\circ} \mathrm{C}$ to $25^{\circ} \mathrm{C}$. Sex and month were included as a factor, with higher partial residuals being determined for July in contrast to May. No clear trend was observed in sex.

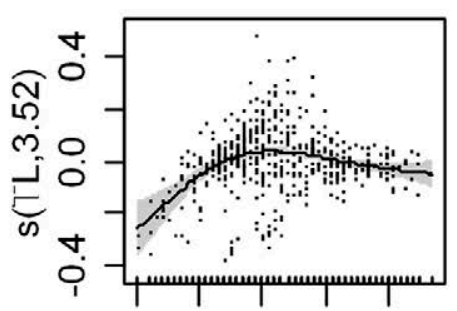

2030405060 TL $[\mathrm{mm}]$
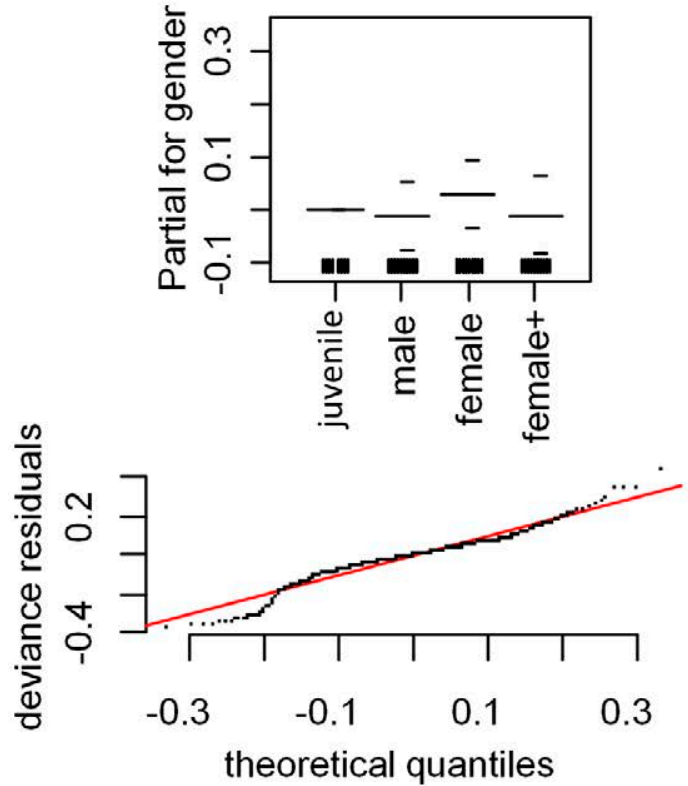

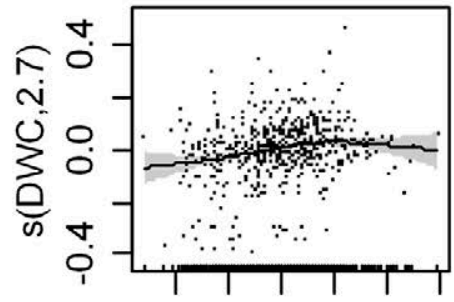

$0.8 \quad 1.2 \quad 1.6$ DWC

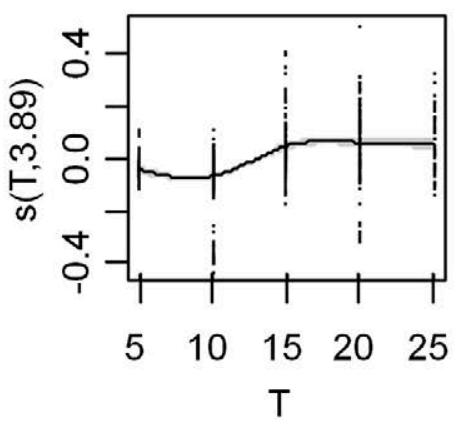

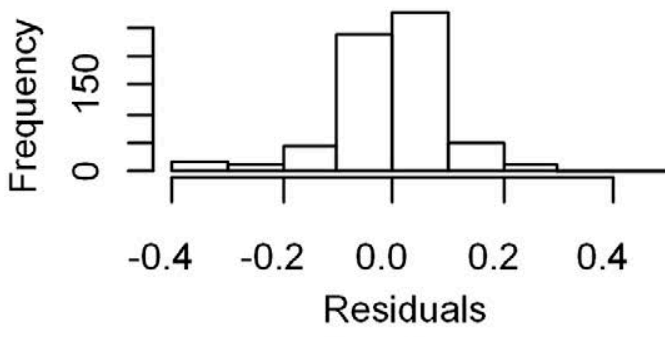

Fig. 3. - Results of the generalized additive model. Partial residuals for growth vs. length (top left), dry weight condition (top middle), temperature (top right), sex (middle left), sampling month (middle right), and distribution of the residuals (lower panels). 

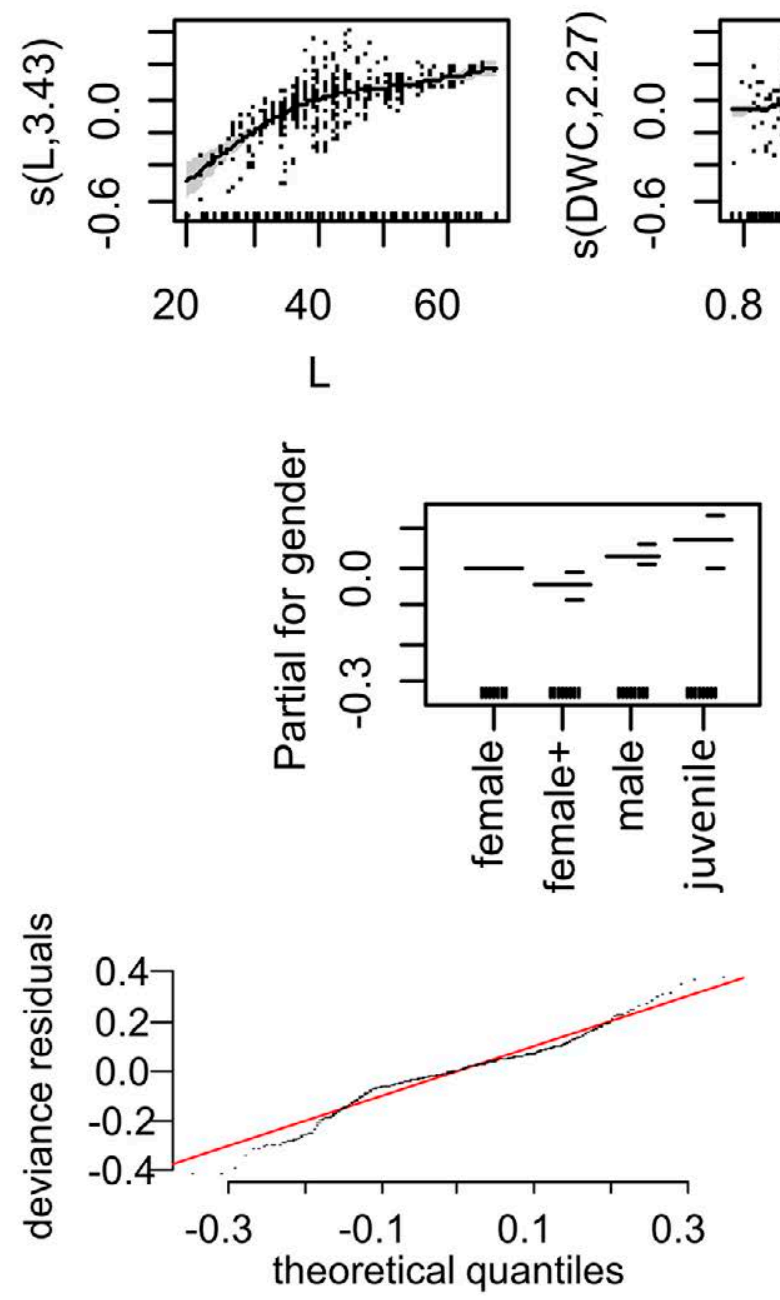

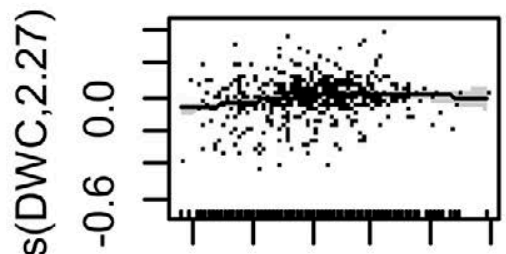

$0.8 \quad 1.2 \quad 1.6$

DWC

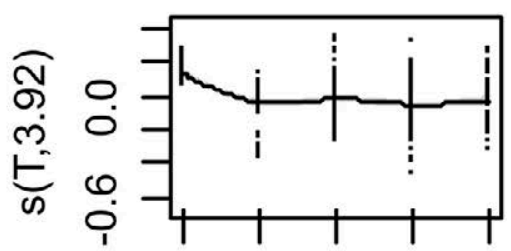

510

20

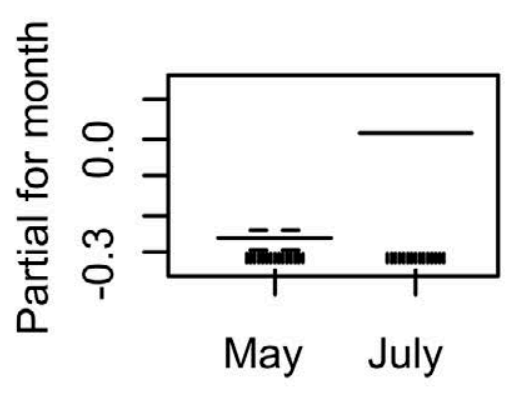

Fig. 4. - Results of the generalized additive model based on the difference between observed growth and predicted growth using the modified Bertalanffy growth model. Partial residuals vs. length (top left), dry weight condition (top middle), temperature (top right), sex (middle left), sampling month (middle right), and distribution of the residuals (lower panels).

\section{Analysis 4. Analysing residuals of observed and predicted GR}

Fitting the extended von Bertalanffy growth function to sex-specific growth data, the following models were obtained:

$$
\begin{gathered}
\mathrm{GR}_{\text {pred }}=0.04324( \pm 0.00201) \mathrm{T}- \\
-0.00325( \pm 0.0025) e^{0.07035( \pm 0.00250) \mathrm{T}} \mathrm{L} \\
\left(\mathrm{r}^{2}=0.44, \mathrm{n}=663\right) \\
\mathrm{fGR}_{\text {pred }}=0.05567( \pm 0.00321) \mathrm{T}- \\
-0.00444(0.00038) e^{0.06892( \pm 0.00251) \mathrm{T}} \mathrm{L} \\
\left(\mathrm{r}^{2}=0.49, \mathrm{n}=386\right) \\
\mathrm{mGR}_{\text {pred }}=0.05494( \pm 0.00369) \mathrm{T}- \\
-0.00463(0.00055) e^{0.07551( \pm 0.00289) \mathrm{T}} \mathrm{L} \\
\left(\mathrm{r}^{2}=0.57, \mathrm{n}=172\right)
\end{gathered}
$$

where $\mathrm{GR}_{\text {pred }}$ was based on all observations (juvenile, male, female, female+), $\mathrm{fGR}_{\text {pred }}$ on female/female+ and $\mathrm{mGR}_{\text {pred }}$ on male observations. Plus/minus deviations in brackets indicate the standard error of the parameter estimate.
Table 3. - Values obtained from the generalized additive model used in Analysis 4: Analysing residuals of observed and predicted growth. Table included the number of knots k', estimated degree of freedom (edf), k-index and the significance value $\mathrm{p}$.

\begin{tabular}{lcccc}
\hline & k' & edf & k-index & p-value \\
\hline s(L) & 4 & 3.428 & 0.537 & 0 \\
s(DWC) & 4 & 2.267 & 0.885 & 0 \\
s(T) & 4 & 3.917 & 0.624 & 0 \\
\hline
\end{tabular}

Fitting a GAM to the growth residuals $\left(\mathrm{GR}-\mathrm{GR}_{\text {pred }}\right)$, all variables except $R D$ were significant and taking sex or month or both factors out did not increase the AIC or explained deviance. Thus, the final model was

$$
\mathrm{GR}-\mathrm{GR}_{\text {pred }}=\mathrm{s}(\mathrm{L})+\mathrm{s}(\mathrm{DWC})+\mathrm{s}(\mathrm{T})+\text { gender }+ \text { month. }
$$

Estimated degrees of freedom were 3.9, 3.4 and 2.3 and $\mathrm{k}$-indices were $0.62,0.54$ and 0.89 for $\mathrm{T}$, TL and DWC, respectively (Table 3 ). The total deviance explained was $52.2 \%$ and the $\mathrm{r}^{2}=0.512$. The TL and DWC smoother increased with increasing TL and DWC, respectively (Fig. 4). July values were again higher than May values and no clear trend in sex or temperature was visible except for slightly higher values for $5^{\circ} \mathrm{C}$. 


\section{RD measurement accuracy}

Corrected correlation coefficients of the standards, measured on the same plate as the samples, were always $r^{2}>0.98$. Repeatability was determined by the coefficient of variation between the calibration standards of all 294 measurements as 8\% for RNA and 10\% for DNA. These measurements were conducted on 21 dates distributed over one year and analysed together with the samples presented in Hufnagl et al. (2010). The variation between wells (each sample was prepared and analysed twice) was $2 \%$ before addition of RNase and DNAse and 6\% after addition. The slope ratio (DNA slope/RNAslope) for laboratory intercalibration (Caldarone et al. 2006) was 0.85 .

\section{DISCUSSION}

The two proxies chosen here, RD and DWC, only explained a very low fraction of the variability observed in individual GRs of brown shrimps, despite the reports that RD explained growth in other species (see introduction) and despite the observation that a significant decrease of both proxies was observed in starvation experiments (Hufnagl et al. 2010). Surprisingly, nor was a difference observed between the faster growing summer (July) cohort and the slower growing overwintering (May), while in the latter a reduced protein synthesis could be expected. In the following section we will briefly summarize and discuss the findings of the statistical analysis and then focus on the reasons why RD might by a bad and DWC only a weak growth proxy for brown shrimp and perhaps shrimps in general.

Several statistical analyses were presented here to be able to tackle all linear and nonlinear as well as additive and interacting effects that might have masked the explanatory power of DWC and RD on GR. In the first analysis we tested whether in general faster-growing individuals showed higher DWC or RD ratios than slow-growing ones, which was the case, but variability in growth at similar RD and DWC was generally high. This first analysis did not account for shrimp length, temperature or sampling month. Taking these factors into account in a direct and linear way, as done in the FAMD analysis, indicated that all these factors are linked and that all of them influenced growth. However, RD and DWC had the least explanatory power and only explained a small part of the variability in the data set. Individual total length, sampling month and ambient temperature were significantly correlated with GR.

Temperature effects in biology are often nonlinear, as, for example, in physiology (e.g. Q10) growth vs. length (e.g. Gompertz equation) or enzymatic activity (e.g. Michaelis Menten). Trying to explain growth of brown shrimp by accounting only for linear effects, as done in the FAMD, might thus be an oversimplification. In the GAM analysis, which accounts for nonlinear effects, we found that RD had no significant effect on GR but we observed a minor but significant positive effect for DWC. This finding indicates that higher GRs are related to higher DWC. Furthermore, we found a maximum in the partial residuals at a shrimp length of about $40 \mathrm{~mm}$. The probability of observing higher GRs increased with increasing temperature and was higher in July than in May. Sex effects were significant but weak and increased the explained deviation by only $1 \%$, which is therefore negligible. As we found nonlinear interactions of length and temperature in an earlier literature study (Hufnagl and Temming 2011b), we took this into account in the last analysis. In that earlier study growth variability of shrimps of the same size and sex reared at the same temperature still displayed high growth variation, which we expected would be explainable by RD or DWC. In the GAM analysis of the residuals (difference of the observed and predicted growth), again RD was not significant, while DWC, T, $\mathrm{L}$, month and sex were. Sex increased the explained deviance by $1.6 \%$ (from $50.6 \%$ to $52.2 \%$ ) and can therefore again be neglected. This is mainly due to the fact that it was already accounted for in growth models $\left(G_{\text {pred }}\right)$ which were sex-specific. A general sex effect is present as the growth models differed, which is in line with earlier studies (Campos et al. 2009, Labat 1977, Meixner 1969). The significant effect of $\mathrm{T}$ and $\mathrm{L}$ on the residuals is surprising, as $\mathrm{T}$ and $\mathrm{L}$ were also already included in the growth model. Mainly at the lowest temperatures $\left(5^{\circ} \mathrm{C}\right)$, higher deviations between the observations and the growth model were observed. For the remaining temperatures no clear trend was visible. The length effect was more pronounced, indicating that for small length classes $(<35 \mathrm{~mm})$ the growth model predicted higher GRs in comparison with the observed ones. One reason might be that we fitted the general growth model also to the juvenile shrimps. No explicit growth model could be fitted due to the limited size range $(20-30 \mathrm{~mm})$. This could have biased the residuals if smaller length classes were dominated by slower growing males, as observed in the sampling area (Hufnagl et al. 2010). Another explanation could be that juvenile growth is generally not isometric, as assumed by the von Bertalanffy growth model. The GAM took this deviation into account but the observed remaining variation could still not be explained by RD or DWC, and also a strong effect of the sampling month remained.

One might argue that shrimp dry weight growth rather than length growth should have been used for a comparison with DWC or RD. However, weight growth (or carbon content) could not be tracked here as measurements were done on individuals. Getting a start and an end value from the same individual is simply not possible. As individual variability was high, so a reference sample from the start time (sampling) would not have helped either. Due to the high number of setae and extremities in relation to the relatively low body weight, the measurement error of wet weight would also have been high, covering the subtle growth differences (partly $0 \mathrm{~mm}$ per moult). Crustaceans also take up water to keep their gills wet and therefore an additional uncertain amount of water is trapped even after the animal has been blotted dry. Measurement errors of up to $10 \%$ can occur (unpublished data). Furthermore, water is permanently replaced by protein during the in- 
ter-moult period (Passano 1960, Perger and Temming 2012), sio wet weight will likely not change much over time although dry weight of course does.

\section{RNA:DNA}

From this study we can conclude that the RD is only of limited use for estimating in situ growth. RD was not significantly related to growth in both GAM analyses and showed only a weak correlation with growth in the FAMD. This is in contrast to species where RD significantly improved growth models (Hovenkamp and Witte 1991, Smith 2003, Peck et al. 2003) but in line with other species where authors reported that RD was not correlated with growth or that RD can only be used during special life stages and under special conditions. For example, for Artemia salina RNA $\mu \mathrm{g}^{-1}$ depended on the growth phase and was higher in the exponential phase (Dagg and Littlepage 1972) or only juvenile GRs of the scallop Euvola ziczac were correlated with RD (Lodeiros et al. 1996). Although RD is generally a good proxy for growth determination of larval fish (Lee et al. 2006, Mathers et al. 1994), in Solea solea $\mathrm{RD}$ could only be used to compare larvae of the same ontogenetic stage (Richard et al. 1991). Anger and Hirche (1990) detected no correspondence of RD to instantaneous GR in carbon and nitrogen of the spider crab, Hyas araneus. RD of Sardina pilchardus varied only with length and food (zooplankton biomass, Chícharo et al. 1998a) and even in well-fed fish larvae a high variability of RD was observed (Bergeron and Boulhic 1994), so high RD values do not necessarily have to correspond to high GR.

There are several factors that might influence RD, but not growth. For shrimps these factors are most likely moulting, maturation and feeding (see more detailed discussion in DWC section). These factors influence a variety of biochemical processes e.g. the RNA level will likely increase to increase the level of moult hormones or steer gonad maturation. Both processes will increase RD although growth is not or even negatively influenced. RD responds to feeding events within a very short time span of the order of days or even hours (see below) but to determine length and weight GR appropriately it takes days to weeks.

RD was determined from $C$. crangon muscle samples which undergo changes during the moult cycle (Chang, 1995; Sánchez-Paz et al. 2003). Mitochondria (also containing RNA) are delocated during the moult cycle (Miyawaki and Tsuruda 1984) and activity and protein degradation is influenced (Boddeke 1976, Regnault 1979, Regnault and Lagardère 1983). Not surprisingly, RD changes related to the moult cycle have been observed e.g. for Homarus americanus post larvae (Juinio et al. 1992). Several hormones are included in the moult process (Hartnoll 2001) and Nott and Mavin (1986) described that metabolic activity of C. crangon peaks at premoult but decreases during the moult phase. RNA regulates all processes mentioned (enzyme and hormone productions) and therefore changes in the RNA concentration most likely occur during moult.
In $C$. crangon and other crustaceans RNA concentrations are therefore most likely not only related to feeding processes but also strongly dependent on the moult process and therefore most probably an unreliable indicator of growth.

Haefner and Spaargaren (1994) showed that biochemical parameters change significantly during vitellogenesis of $C$. crangon. Chícharo et al. (2007) observed higher RNA.DW ${ }^{-1}$ in female than in male $C$. crangon and concluded that a possible reason might be maturation or sex-specific behaviour. Here, range and variability between male and female shrimps was comparable, which might indicate that maturation will not be the main factor affecting RD.

In addition to moulting and maturation, mainly feeding, short-term starvation during moult and the quick response of RD to feeding events will cause a mismatch between RD and GR (see also Hufnagl et al. 2010). In bivalves (Norkko et al. 2006), fish larvae (Bergeron 2000), fish juveniles (Malloy and Targett 1994, Richard et al. 1991) and decapods (Rosa and Nunes 2004) RD is influenced by feeding and starving within days in bivalves or hours (Lee et al. 2006, Chícharo et al. 1998b, Lough et al. 1996). This stands in conflict with the experimental time span (weeks) necessary to determine GR in $C$. crangon. Nevertheless, it was worthwhile testing and analysing it, as temperature, feeding and light conditions in the experiment were kept as constant as possible and all shrimps were fed the same diet. Assuming that RD mainly reflects metabolic and enzymatic processes, a link between constantly high growth and high RD could have been visible.

Injuries might also have influenced the results, as regeneration might reduce growth of $C$. crangon (Tiews 1970). Regeneration under ad libitum feeding could therefore lead to high RD ratios but low GRs. Only healthy (all extremities no black spots) animals were used in our experiments to minimize this effect, but animals were reared in groups to allow a larger sample size and cannibalism is well known for brown shrimp (Plagmann 1939).

\section{Accuracy}

Measurement errors cannot be fully excluded due to the determination method. Samples were freeze-dried, the muscle was dissected out on ice to prevent DNA and especially RNA degradation, and every sample was analysed twice. As in our previous study (Hufnagl et al. 2010) significant declining trends in RD in starvation experiments were determined and samples were measured alongside the samples presented here, it can be assumed that the observed variation in $\mathrm{RD}$ and the missing significant link to growth is due to other factors than measurement error.

\section{Dry weight condition index}

Our results indicate that DWC is, like RD, only of limited use as a growth proxy, but that the probability was high that an animal with high DWC also displayed 
higher GR. Nevertheless, owing to the existing variability (Fig. 1) any growth prediction based on DWC will still be erroneous. Since TL and dry weight can be determined with sufficient accuracy, it can be assumed that growth variability must largely result from other sources than measurement error. These might be differences in the stage of the moult cycle, the stage of maturation of female shrimp and individual feeding behaviour, as described above.

Inter-moult periods vary between individuals, and the timespan to the next moult event could not be determined here. Individual moult events were only tracked for marked shrimps, and although this provides the time span since the last moult, it does not provide information on when the next moult will take place. Since crustaceans exhibit continuous weight growth but incremental (discontinuous) length growth, which is hindered by the hard structure of the exoskeleton (Blaxter and Outhward 1991), DWC can vary according to the moult stage (Perger and Temming 2012). Hence, growth is a steady replacement of water by protein (Rosa and Nunes 2004), and two similar sized shrimps can display different dry weights only because they are in different stages of the moult cycle. Additionally, in calculating the DWC, the whole animal is considered and differences in the thickness or calcification of the carapace might influence this proxy. Up to $17 \%$ of the whole dry weight can be made up by the exhuvia (Regnault and Luquet 1978).

Furthermore, DWC is effected by weight loss due to higher energy demands or food deprivation. Several days before ecdysis, crustaceans stop feeding (Blaxter and Outhward 1991). Effects of this pre-moult starvation and the energy loss during that phase are discussed differently. In most crustaceans, glycogen, glucose and lipids derived from the hepatopancreas and haemolymph are used to fuel the moulting process (SánchezPaz et al. 2007, Clifford and Brick 1983, Barcley et al. 1983). These substances have a high energy density and the influence should therefore be small on DWC. On the other hand, dry weight is mainly a measure of muscle protein, which is expected to decrease when growth is low (negative), which would be captured by the DWC (e.g. Hufnagl et al. 2010). During the moult process, Regnault and Lagardère (1983) assumed that C. crangon loses $10 \%$ of its protein biomass due to additional energy demands.

The second factor influencing dry weight is maturation (ovary development) of female shrimps. At about $55 \mathrm{~mm}$ TL, $50 \%$ of females carry eggs (Henderson and Holmes 1987, Boddeke 1961). Energy required for gonadogenesis might influence somatic GR (Taylor and Peck 2004). According to Haefner and Spaargaren (1993) the weight of the ovary can increase the body weight of C. crangon by $5.5 \%$ and, according to Henderson and Holmes (1987), the smallest egg-bearing females were $\sim 38 \mathrm{~mm}$. In our experiments, less variability in GR per DWC (Fig. 1) was determined for male in comparison to female shrimps. This might be due to the influence of maturation.

C. crangon feeds mainly at night (Feller 2006), and Pihl and Rosenberg (1984) determined that the stomach content is about $1 \%$ to $2 \%$ of the body weight. This fact might add to the variability. In this study shrimps were fed and sampled at comparable times, but differences in individual feeding behaviour could have contributed to the variability.

\section{PERSPECTIVE}

Although the hypothesis that RD or DWC can be applied as growth proxies had to be rejected here, it cannot be rejected per se due to factors not included here. Future work should therefore focus on changes of DWC and RD over the moult cycle and maturation in relation to growth.

\section{ACKNOWLEDGEMENTS}

We thank J.P. Hermann for help with the experimental design, F. Buchholz, R. Saborowski and the AWI team for support during the experiments performed on Helgoland and M. Peck for help in developing the RD method. The study was financially supported by the Federal Ministry of Food, Agriculture and Consumer Protection, Germany Project No. 03HS030.

\section{REFERENCES}

Anger K., Hirche H.-J. 1990. Nucleic acids and growth of larval and early juvenile spider crab, Hyas araneaus. Mar. Biol. 105: 403-411. https://doi.org/10,1007/BF01316311

Barcley M.C., Dall W., Smith D.M. 1983. Changes in lipid and protein during starvation and the moulting cycle in the tiger prawn Penaeus esculentus Haswell. J. Exp. Mar. Biol. Ecol. 68: 229-244.

https://doi.org/10.1016/0022-0981(83)90055-2

Bergeron J.-P. 2000. Effect of strong winds on the nutritional condition of anchovy (Engraulis encrasicolus L.) larvae in the Bay of Biscay, Norhtern Atlantic, as inferred from an early field application of DNA/C index. ICES J. Mar. Sci. 57: 249-255. https://doi.org/10.1006/jmsc.2000.0642

Bergeron J.-P., Boulhic M. 1994. Rapport ARN/ADN et évaluation de l'état nutritionelle et de la croissance des larves de poissions marins: un essai de mise au point expérimentale chez la sole (Solea solea L.). ICES J. Mar. Sci. 51: 181-190. https://doi.org/10.1006/jmsc.1994.1019

Blaxter J.H.S.B., Outhward A.J.S. 1991. Moulting and growth. Adv. Mar. Biol. 27: 213-250. https://doi.org/10.1016/S0065-2881(08)60172-8

Boddeke R. 1961. Sex in the brown shrimp (Crangon crangon). ICES Shellfish Committee C II 50.

Boddeke R. 1976. The seasonal migration of the brown shrimp Crangon crangon. N. J. Sea Res. 10: 103-130. https://doi.org/10.1016/0077-7579(76)90006-5

Buckley B.A., Szmant A.M. 2004. RNA/DNA ratios as indicators of metabolic activity in four species of Caribbean reef-building corals. Mar. Ecol. Prog. Ser. 282: 143-149. https://doi.org/10.3354/meps282143

Buckley L., Caldarone E., Ong T.L. 1999. RNA-DNA ratio and other nucleic acid-based indicators for growth and condition of marine fishes. Hydrobiologia 401: 265-277. https://doi.org/10.1023/A: 1003798613241

Caldarone E.M., Wagner M., St.Onge-Burns J., et al. 2001. Protocol and Guide for Estimating Nucleic Acids in Larval Fish Using a Fluorescence Microplate Reader. Northeast Fisheries Science Center Reference Document 01-11, -28. National Oceanic and Atmospheric Administration, National Marine Fisheries Service, Woods Hole, Massachusetts.

Caldarone E.M., Clemmesen C.M., Berdalet E., et al. 2006. Intercalibration of four spectrofluorometric protocols for measuring RNA/DNA ratios in larval and juvenile fish. Limnol. Oceanogr. Methods 4: 153-163. 
https://doi.org/10.4319/lom.2006.4.153

Campos J., van der Veer H. 2008. Autecology of Crangon crangon (L.) with an emphasis on latitudinal trends. Oceanogr. Mar. Biol. Ann. Rev. 46: 65-104.

Campos J., Van der Veer H.W., Freitas V., et al. 2009. Contribution of different generations of the brown shrimp Crangon crangon (L.) in the Dutch Wadden Sea to commercial fisheries: A dynamic energy budget approach. J. Sea Res. 62: 106-113. https://doi.org/10.1016/j.seares.2009.07.007

Chang E.S. 1995. Physiological and biochemical changes during the moult cycle in decapod crustaceans: an overview. J. Exp. Mar. Biol. Ecol. 193: 1-14.

https://doi.org/10.1016/0022-0981(95)00106-9

Chícharo M.A., Chícharo L., Valdés L., et al. 1998a. Does the nutritional condition limit survival potential of the sardine Sardina pilchardus (Wlabaum, 1792) larvae off the north coast of Spain? RNA/DNA ratios and their variability. Fish. Res. 39: 43-54 https://doi.org/10.1016/S0165-7836(98)00167-2

Chícharo M.A., Chícharo L., Valdés L., et al. 1998b. Estimation of starvation and diel variation of the RNA/DNA ratios in fieldcaught Sardina pilchardus larvae off the north of Spain. Mar. Ecol. Prog. Ser. 164: 273-283. https://doi.org/10.3354/meps 164273

Chícharo M.A., Amaral A., Morais P., et al. 2007. Effect of sex on ratios and concentrations of DNA and RNA in three marine species. Mar. Ecol. Prog. Ser. 332: 241-245. https://doi.org/10.3354/meps332241

Clifford H.C., Brick R.W. 1983. Nutritional physiology of the freshwater shrimp Macrobrachium rosenbergii (De Man) - I. Substrate metabolism in fasting juvenile shrimp. Comp. Biochem. Physiol. 74A: 561-568 https://doi.org/10.1016/0300-9629(83)90548-0

Dagg M.J., Littlepage J.L. 1972. Relationships between growth rate and RNA, DNA, Protein and dry weight in Artemia salina and Euchaeta elongata. Mar. Biol. 17: 162-170.

Dalley R. 1980. The survival and developement of the shrimp Crangon crangon (L.), reared in the laboratory under non-circadian light-dark cycles. J. Exp. Mar. Biol. Ecol. 47: 101-112. https://doi.org/10.1016/0022-0981(80)90105-7

Edwards R.R.C. 1978. Effects of water-soluble oil fractions on metabolism, growth and carbon budget in the shrimp Crangon crangon. Mar. Biol. 46: 259-265. https://doi.org/10.1007/BF00390687

Feller R.J. 2006. Weak meiofaunal trophic linkages in Crangon crangon and Cracinus maenas. J. Exp. Mar. Biol. Ecol. 330: 274-283. https://doi.org/10.1016/j.jembe.2005.12.033

Greve W., Reiners F., Nast J., et al. 2004. Helgoland Roads mesoand macrozooplankton time series 1974 to 2004 Lessons from 30 years of single spot, high frequency sampling at the only off-shore island of the North Sea. Helg. Mar. Res. 58: 274-288. https://doi.org/10.1007/s10152-004-0191-5

Haefner P.A., Spaargaren D.H. 1993. Interactions of ovary and hepatopancreas during the reproductive cycle of Crangon crangon (L.). I. Weight and volume relationships. J. Crust. Biol. 13: 523-531. https://doi.org/10.2307/1548792

Haefner P.A., Spaargaren D.H. 1994. Interactions of ovary and hepatopancreas during the reproductive cycle of Crangon crangon (L.). II: Biochemical relationships. J. Crust. Biol. 14: 6-19. https://doi.org/10.2307/1549050

Hartnoll R. 2001. Growth in Crustacea - twenty years on. Hydrobiologia 449: 111-122. https://doi.org/10.1023/A: 1017597104367

Henderson P.A., Holmes R.H.A. 1987. On the population biology of the common shrimp Crangon crangon (L.) (Crustacea: Caridea) in the Severn Estuary and Bristol Channel. J. Mar. Biol. Ass. U.K. 67: 825-847. https://doi.org/10.1017/S0025315400057076

Hovenkamp F., Witte J.I.J. 1991. Growth, otolith growth and RNA DNA ratios of larval plaice Pleuronectes platessa in the North Sea 1987 to 1989. Mar. Ecol. Prog. Ser. 70: 105-116. https://doi.org/10.3354/meps070105

Hufnagl M., Temming A. 2011a. Growth in the brown shrimp Crangon crangon. I. Effects of food, temperature, size, sex, moulting, and cohort. Mar. Ecol. Prog. Ser. 435: 141-154 https://doi.org/10.3354/meps09223

Hufnagl M., Temming A. 2011b. Growth in the brown shrimp Crangon crangon. II. Meta-analysis and modelling. Mar. Ecol. Prog. Ser. 435: 155-172. https://doi.org/10.3354/meps09224

Hufnagl M., Temming A., Dänhardt A., et al. 2010. Is Crangon crangon (L. 1758, Decapoda, Caridea) food limited in the Wadden Sea? J. Sea Res. 64: 386-400. https://doi.org/10.1016/j.seares.2010.06.001

Juinio M.A.R., Cobb J.S. 1994. Estimation of recent growth rates of field-caught postlarval amercian lobsters, Homarus americanus, from RNA: DNA ratios. Can. J. Fish. Aqu. Sci. 51: 286-294. https://doi.org/10.1139/f94-030

Juinio M.A.R., Cobb J.S., Bengtson D., et al. 1992. Changes in nucleic acids over the moult cycle in relation to food availability and temperature in Homarus americanus postlarvae. Mar. Biol. 114: $1-10$

Kilada R., Sainte-Marie B., Rochette R., et al. 2012. Direct determination of age in shrimps, crabs, and lobsters. Can. J. Fish. Aqu. Sci. 69: 1728-1733. https://doi.org/10.1139/cjfas-2012-0254

Labat J.-P. 1977. Écologie de Crangon crangon (L.) (Decapoda, Caridea) dans un étang de la côte languedocienne. Vie Milieu XXVII: 273-292.

Lê S., Josse J., Husson F. 2008. FactoMineR: An R Package for Multivariate Analysis. J. Stat. Soft. 25: 1 https://doi.org/10.18637/jss.v025.i01

Lee O., Danilowicz B.S., Dickey-Collas M. 2006. Temporal and spatial variability in growth and condition of dab (Limanda limanda) and sprat (Sprattus sprattus) larvae in the Irish Sea. Fish. Oceanogr. 15: 490-507. https://doi.org/10.1111/j.1365-2419.2006.00406.x

Lodeiros C.J.M. Fernández R.I., Bonmatí A., et al. 1996. Relation of RNA/DNA ratios to growth for the scallop Euvola (Pecten) ziczac in suspended culture. Mar. Biol. 126: 245-251. https://doi.org/10.1007/BF00347449

Lough R.G., Caldarone E., Rotunno T.K., et al. 1996. Vertical distribution of cod and haddock eggs and larvae, feeding and condition in stratified and mixed waters on southern Georges Bank, May 1992. Deep-Sea Res. II 43: 1875-1904. https://doi.org/10.1016/S0967-0645(96)00053-7

Malloy K.D., Targett T.E. 1994. The use of RNA: DNA ratios to predict growth limitations of juvenile summer flounder (Paralichthys dentatus) from Delawarer North Carolina estuaries. Mar. Biol. 118: 367-375 https://doi.org/10.1007/BF00350293

Mathers E.M., Houlihan D.F., Buren L.J. 1994. RNA, DNA and protein concentrations in fed and starved herring Clupea haerengus larvae. Mar. Ecol. Prog. Ser. 107: 223-231. https://doi.org/10.3354/meps 107223

Meixner R. 1969. Wachstum, Häutung und Fortpflanzung von Crangon crangon (L.) bei Einzelaufzucht. Berichte der Deutschen Wissenschaftlichen Kommission für Meeresforschung 20: 93-111.

Miyawaki M., Tsuruda T. 1984. The transposition of Mitochondria in the hindgut epithelial cells of the crayfish, Procambarus clar$k i$, during the moult cycle. Proc. Jap. Acad. Ser. B 60: 81-84. https://doi.org/10.2183/pjab.60.8

Moss S.M. 1994a. Growth rates, nucleic acid concentrations, and RNA/DNA ratios of juvenile white shrimp, Penaeus vannamei Boone, fed different algal diets. J. Exp. Mar. Biol. Ecol. 182: 193-204. https://doi.org/10.1016/0022-0981(94)90051-5

Moss S.M. 1994b. Use of nucleic acids as indicators of growth in juvenile white shrimp, Penaeus vannamei. Mar. Biol. 120: 359-367. https://doi.org/10.1007/BF00680209

Norkko J., Thrush S.F., Wells R.M.G. 2006. Indicators of short-term growth in bivalves: Detecting environmental change across ecological scale. J. Exp. Mar. Biol. Ecol. 337: 38-48. https://doi.org/10.1016/j.jembe.2006.06.003

Nott J.A., Mavin L.J. 1986. Adaptation of a quantitative programme for the X-ray analysis of solubilized tissue as microdroplets in the transmission electron microscope: application to the moult cycle of the shrimp Crangon crangon (L). Histochem. J. 18: 507-518 https://doi.org/10.1007/BF01675619

Passano L.M. 1960. Molting and its control. In: Waterman, T.H. (ed.), The Physiology of Crustacea, Vol. I. Academic Press, New York - London, pp. 473-536. https://doi.oro/10.1016/B978-0-12-395628-6.50021-X

Peck M.A., Buckley L.J., Caldarone E.M., et al. 2003. Effects of food consumption and temperature on growth rate and biochemical-based indicators of growth in early juvenile Atlantic 
cod Gadus morhua and haddock Melanogrammus aeglefinus. Mar. Ecol. Prog. Ser. 251: 233-243. https://doi.org/10.3354/meps251233

Perger R., Temming A. 2012. A new method to determine in situ growth rates of decapod shrimp: a case study with brown shrimp Crangon crangon. Mar. Biol. 159: 1209-1222. https://doi.org/10.1007/s00227-012-1901-1

Pihl L., Rosenberg R. 1984. Food selection and consumption of the shrimp Crangon crangon in some shallow marine areas in western Sweden. Mar. Ecol. Prog. Ser. 15: 159-168. https://doi.org/10.3354/meps015159

Plagmann J. 1939. Ernährungsbiologie der Garnele (Crangon vulgaris Fabr.). Helg. Wiss. Meeresunt. 2: 113-162. https://doi.org/10.1007/BF02253516

Regnault M. 1979. Ammonia excretion of the sand-shrimp Crangon crangon (L.) during the moult cycle. J. Comp. Physiol. 133: 199-204. https://doi.org/10.1007/BF00691466

Regnault M., Lagardère J.P. 1983. Effects of ambient noise on the metabolic level of Crangon crangon (Decapoda, Natantia). Mar. Ecol. Prog. Ser. 11: 71-78. https://doi.org/10.3354/meps011071

Regnault M., Luquet P. 1978. Variations quantitatives de l'acide desoxyribonucléique (ADN), au cours de cycle de mue, dans les téguments, le muscle et l'hépatopancréas de la crevette Crangon crangon. J. Physiol. Paris 74: 21-30.

Richard P., Bergeron J.-P., Boulhic M., et al. 1991. Effect of starvation on RNA, DNA and protein content of laboratory-reared larvae and juveniles of Solea solea. Mar. Ecol. Prog. Ser. 72: 69-77.

https://doi.org/10.3354/meps072069

Rosa R., Nunes M.L. 2004. RNA, DNA and protein concentrations and amino acid profiles of deep-sea decapod Aristeus antennatus: An indication for seasonal variations of nutrition and growth. Aqu. Liv. Res. 17: 25-30. https://doi.org/10.1051/alr: 2004003

Sánchez-Paz A., García-Carreño F.L., Muhlia-Almazán A., et al. 2003. Differential expression of trypsin mRNA in the white shrimp (Penaeus vannamei) midgut gland under starvation conditions. J. Exp. Mar. Biol. Ecol. 292: 1-17.

https://doi.org/10.1016/S0022-0981(03)00142-4
Sánchez-Paz A., García-Carreño F.L., Hernández-López J., et al. 2007. Effect of short-term starvation on hepatopancreas and plasma energy reserves of the Pacific white shrimp (Litopenaeus vannamei). J. Exp. Mar. Biol. Ecol. 340: 184-193. https://doi.org/10.1016/j.jembe 2006.09.006

Sheehy M.R.J., Bannister R.C.A., Wickins J.F., et al. 1999. New perspectives on the growth and longevity of the European lobster (Homarus gammarus). Can. J. Fish. Aqu. Sci. 56: 1904-1915. https://doi.org/10.1139/f99-116

Siegel V., Damm U., Neudecker T. 2008. Sex-ratio, seasonality and long-term variation in maturation and spawning of the brown shrimp Crangon crangon (L.) in the German Bight (North Sea). Helg. Mar. Res. 62: 339-349. https://doi.org/10.1007/s10152-008-0121-z

Smith T.R. 2003. RNA-DNA ratio in scales from juvenile cod provides a nonlethal measure of feeding condition. Trans. Am. Fish. Soc. 132: 9-17. https://doi.org/10.1577/1548-8659(2003)132<0009: RDRISF $>2.0 . \mathrm{CO} ; 2$

Taylor D.L., Peck M.A. 2004. Daily energy requirements and trophic positioning of the sand shrimp Crangon septemspinosa. Mar. Biol. 145: 167-177. https://doi.org/10.1007/s00227-004-1299-5

Tiews K. 1970. Synopsis of biological data on the common shrimp Crangon crangon (Linaeus, 1758). FAO Fish. Rep. 4: 1167-1223.

van Lissa J.H.L. 1977. Aantallen, voedselopname, groei en produktie van de garnaal (Crangon crangon L.) in een getijdengebied, alsmede de voedselopname en groei onder laboratoriumomstandigheden. Interne Verslagen Nederlands Instituut voor Onderzoek der Zee, Texel, 101 pp.

von Bertalanffy L. 1934. Untersuchungen über die Gesetzlichkeit des Wachstums I. Teil: Allgemeine Grundlagen der Theorie; Mathematische und Physiologische Gesetzlichkeiten des Wachstums bei Wassertieren. Dev. Genes Evol. 131: 613-651.

Wagner M., Durbin E., Buckley L. 1998. RNA: DNA ratios as indicators of nutritional condition of the copepod Calanus finmarchicus. Mar. Ecol. Prog. Ser. 162: 173-181. https://doi.org/10.3354/meps162173 